\title{
Édipo foucaultiano
}

\author{
MARCOS ALEXANDRE GOMES NALLI
}

RESUMO: Neste artigo, o autor pretende recuperar os elementos teóricoconceituais fundamentais à análise genealógica baseando-se na Segunda Conferência de $A$ verdade $e$ as formas jurídicas de Foucault, identificando principalmente uma concepção pragmática de discurso, vinculada de modo fundamental à concepção genealógica de poder, com seus desdobramentos na questão do estado e do governo, bem como na temática do indivíduo.

\section{Introdução}

ostaria, neste trabalho, de discorrer sobre algumas das principais intuições da genealogia do poder, tomando como base uma das cinco conferências que o filósofo francês Michel Foucault ministrou em 1973, na Pontifícia Universidade Católica do Rio de Janeiro, e que ficaram conhecidas como $A$ verdade e as formas jurídicas. A conferência em questão é a segunda, que toma a tragédia Édipo-Rei, de Sófocles, como objeto de análise e como paradigma analítico, que doravante denominaremos Sobre o Édipo. O objetivo aqui pretendido é averiguar a presença de elementos teóricos e conceituais que permitam considerar o texto em questão como uma legítima análise, bem como sua singularidade tanto em relação à fase genealógica quanto em relação à fase arqueológica.

PALAVRAS-CHAVE: genealogia, discurso, poder, governo, indivíduo.
Professor do Departamento de Filosofia do $\mathrm{CLCH}$ - UEL 
Neste sentido, apresentaremos: Uma breve contextualização histórica e teórico-conceitual dessas conferências na obra de Foucault; e uma reconstrução e análise dos argumentos genealógicos desenvolvidos na conferência Sobre o Édipo, mediante sua inter-relação com outros textos desta fase.

\section{Contexto teórico-intelectual de A verdade e as formas jurídicas}

$\mathrm{O}$ ciclo de conferências intitulado $A$ verdade e as formas jurídicas, proferido por Foucault na PUC do Rio de Janeiro, de 21 a 25 de maio de 1973, consistiu basicamente em cinco conferências, cada uma com um tema distinto, formando um todo único em que suas partes eram devidamente concatenadas a partir de um critério de sucessão histórica, ao mesmo tempo que apresentava uma homogeneidade temática geral.

Isto é válido, ao menos, para as quatro últimas conferências, que têm como tema e objetivo genéricos uma exposição sobre como as sociedades ocidentais trataram a questão da verdade a partir das práticas e instituições sócio-jurídicas, no decorrer dos grandes períodos históricos (estabelecidos muito mais por fins didáticos, isto é de exposição, do que metodológicos).

A primeira conferência, aparentemente, destoa do conjunto dado que não tem como tema o mesmo que permeia (ainda que o anuncie) as quatro conferências que a sucedem. Contudo, sua função é precisa: ela tem como objetivo demarcar metodologicamente a análise foucaultiana como um todo, e aquelas que se seguiram naqueles dias, em particular.

Vale a pena traçar algumas considerações sobre a primeira conferência, uma vez que permite, parcialmente, recriar o contexto teóricointelectual foucaultiano daquele momento, precisamente da fase genealógica de Foucault.

Nesta primeira conferência, Foucault faz seu público perceber que: a) sua pesquisa é propriamente histórica; b) consistindo, simultaneamente, numa análise dos discursos; e c) numa reelaboração da teoria do sujeito na medida que localiza "a emergência de novas formas de subjetividade" (Foucault, 1994b, p. 540). Posteriormente, ele propõe como sua hipótese duas histórias de verdade onde, na primeira se apresenta a verdade a partir de princípios reguladores inerentes à ciência (assim, esta história da verdade coincide com a história das ciências), e uma história "externa" da verdade a partir da definição das regras dos jogos de produção de verdade, a partir do nascimento de "certas formas de subjetividade, certos domínios de objeto, certos tipos de saber" (Foucault, 1994b, p. 541).

O restante dessa primeira conferência consiste numa análise do tratamento nietzschiano a alguns termos, dois especificamente: invenção (Erfindung) e origem (Ursprung). Termos simultaneamente próximos e radicalmente distintos. Próximos na medida em que para Nietzsche (segundo Foucault, mas também para ele mesmo), Erfindung, invenção, invoca Ursprung, origem. Isto é, nem Nietzsche nem Foucault conseguem - e nem pretendem - tratar da invenção sem se referir à origem e vice-versa; 
em outros termos, "invenção" e "origem" se invocam reciprocamente. Contudo, são termos distintos pois tanto Nietzsche quanto Foucault não concebem essa invocação recíproca como uma exigência de sinonímia ou de complementação; antes, são termos antagônicos e opostos. Quando Nietzsche e Foucault falam de "invenção" é para não falarem de "origem" (cf. Foucault, 1994b, p. 543).

Com base nessa oposição entre invenção e origem, Nietzsche e Foucault podem caracterizar o conhecimento como uma invenção que, portanto, não tem origem (o que significa também dizer que o conhecimento não tem fundamento último), sendo contra-natural, e também que não há afinidade alguma, não há um elo de ligação entre conhecimento e objeto a conhecer: "não é natural à natureza ser conhecida" (Foucault, 1994b, p. 546).

Curiosamente, vale observar a semelhança dessa parte da primeira conferência com um outro texto, anterior a $A$ verdade e as formas jurídicas, mais precisamente de 1971, por ocasião da homenagem a Jean Hippolite. O texto em questão é Nietzsche, la généalogie, l'histoire. Trata-se, certamente, de um texto que não pode, e nem deve, ser caracterizado propriamente como um texto de análise e de história da filosofia que se volta para um outro aspecto da obra de Friederich Nietzsche (em suma, utilizando uma expressão nos moldes foucaultianos, não se trata de um comentário). Trata-se de uma leitura que é tanto diálogo quanto apropriação com fins instrumentais, quer dizer: Foucault, em Nietzsche, la généalogie, l'histoire, estabelece um texto-programa, no qual se propõe alguns princípios metodológicos como a oposição entre origem e invenção, o conceito de "interpretação" e outros.

Certamente, o trecho contido na primeira conferência de $A$ verdade e as formas jurídicas acerca de Nietzsche é uma alusão sintetizada a esse seu outro texto sobre Nietzsche que chamei de "texto-programa". Basta observar que, naquele, os termos nietzschianos discutidos vão muito além dos de "invenção" e "origem" (ainda que nele ocupem uma posição nuclear), únicos termos que Foucault cita na primeira conferência.

No texto sobre Nietzsche o que está em jogo para Foucault é, por um lado, admitir seu débito intelectual sem, contudo, filiar-se obstinada e subservientemente àquele filósofo, ou seja, permitindo-se, ainda assim, resguardar sua autonomia intelectual e oferecer alguma resistência, ainda que parcial. Por outro lado, o que Foucault efetua é uma precisão do conceito e de sua concepção de interpretação distinguindo-a completamente de uma interpretação hermenêutica. O que Foucault fez, ou pretendeu fazer, não é uma interpretação pelo sentido, ou pela significação última, profunda e recôndita das coisas, mas uma reorganização dos elementos, dos seus jogos de força e dos sistemas de regras que lhe são inerentes.

E como o conhecimento é invenção e, portanto, não-natural, é interpretação. Desse modo a genealogia enquanto interpretação é história/ interpretação de outras interpretações; por isso, e com base na definição proposta por Foucault ao termo "interpretação", então a genealogia 
foucaultiana é subversiva, na medida em que se impõe à força sobre os elementos constituintes dos objetos das interpretações genealógicas - as outras interpretações - obrigando-os a se reorganizarem. Como precisa Scarlett Marton:

"a tarefa genealógica consistiria, segundo Foucault, em interpretar as interpretações. Ao genealogista, caberia investigar que forças dominam num dado momento, impondo uma nova direção a sistemas de regras estabelecidos" (Marton, 1985, p. 44).

É com base nesses princípios metodológicos que Foucault norteia suas investigações genealógicas das quais a segunda conferência - Sobre o Édipo - de A verdade e as formas jurídicas é um caso exemplar, como pretendo mostrar, neste trabalho, em momento oportuno.

Há ainda outros elementos que devem ser levados em consideração para a caracterização do contexto em que $A$ verdade e as formas jurídicas está inserido. Quando essas conferências são proferidas, Foucault já está na sua fase genealógica, como se convencionou chamar as suas investigações e escritos desses primeiros anos da década de 70. Como se pode observar, já desde A ordem do discurso, sua aula inaugural, proferida por ocasião de seu ingresso como professor do Collège de France, de 2 de dezembro de 1970, Foucault recorre ao termo "genealogia" para se referir a sua proposta de análise/interpretação, ainda que naquele momento compreenda a genealogia como uma das suas atuações analíticas, sendo complementada por aquilo que chamou de "descrições críticas".

Deve-se observar, portanto, que naquela ocasião de sua aula inaugural, "genealogia" não designava nem o procedimento metodológico, nem a análise efetuada; o termo em questão apenas designava uma das faces, das atuações analíticas foucaultianas. Em suma, Foucault concebia, naquele instante, que sua análise tem dois momentos e duas ações que são distintas e complementares: uma descrição crítica e uma descrição genealógica.

Rapidamente, essa concepção acerca da genealogia mudou a ponto do termo designar não mais uma faceta, mas a própria análise foucaultiana daquele período. Basta ver que, em 1971, no texto Nietzsche, la généalogie, l'histoire o termo "genealogia" é tratado como método, história, interpretação, mas sem carecer de complementações. As descrições críticas são absorvidas a partir de então pelas genealógicas.

De qualquer modo, o que importa destacar é que a sua entrada no Collège de France coincide com um redirecionamento teórico da produção foucaultiana: a partir de 1971 é a questão da prisão que lhe interessa (cf. Éribon, 1990, p. 201). Basta observar os títulos e temas de seus cursos naquela instituição na primeira metade da década de 70: em 1970-1971, ele propõe como título de seu primeiro curso $A$ vontade de saber no qual contrasta os modelos teóricos aristotélico e nietzschiano. Para o ano letivo de 1971-1972, o tema do curso foi Teoria e instituições penais, no qual 
pretendia averiguar os elementos históricos preliminares às instituições penais francesas do séc. XIX: primeiramente se estudou o inquérito na sua relação com a formação do estado medieval, bem como se dedicou "ao aparecimento, na França do séc. XVII, de novas formas de controle sociais" (Foucault, $1979 b$, p. 172). Nesse período letivo um fato marcante foi o trabalho conjunto, coordenado por Foucault, na análise do memorial e de todos os discursos em torno do parricida Pierre Rivière.

No período letivo de 1972-1973, Foucault abordou analiticamente quatro táticas punitivas presentes no regime penal da Idade Clássica: o exílio, a reconversão do delito em obrigação financeira, o "apropriar-se do corpo e nele inscrever as marcas do poder" (Foucault, 1979a, p. 174), e o internamento. Esse curso foi conhecido como A sociedade punitiva. É nesse ano letivo que o dossiê sobre Pierre Rivière foi organizado e publicado ${ }^{1}$. Em 1974-1975, o tema proposto é $O$ poder psiquiátrico, que tratou da arquitetura hospitalar no século XVIII e da experiência médico-legal em psiquiatria após 1830. O curso de 1975-1976 abordou a apreensão da anormalidade pela psicologia; seu título foi Os anormais. Nesse ano de 1975, em fevereiro, Foucault publica Surveiller et punir, e em dezembro de 1976 publica o primeiro volume de sua Histoire de la sexualité: la volonté de savoir.

O que se percebe é que, nesses primeiros anos da década de 70, em suas linhas gerais, o objeto das investigações e análises foucaultianas é a prisão e as práticas jurídicas que lhe são correlatas. O resultado "último" dessas investigações culminou no livro Surveiller et punir. Nesse contexto, A verdade e as formas jurídicas pode ser caracterizada como uma das etapas desses anos de investigações e uma apresentação pública (ao menos para além dos muros do Collège de France) dos resultados parciais de seus cursos/investigações. Assim, essas conferências não se destacam propriamente por sua temática, isto é, não há inovação, não há riscos de incorrer em vias jamais desbravadas. Foucault simplesmente expõe os resultados de suas pesquisas, oferecendo ao público brasileiro os frutos das suas investigações dos últimos anos.

\section{Análise da genealogia foucaultiana a partir de Sobre o Édipo}

O Édipo foucaultiano não é, certamente, nem o Édipo dos mitos, como Freud e Lévi-Strauss apresentam; tampouco é o mesmo que Deleuze e Guattari apresentam em seu L'Anti-Oedipe (que é uma crítica àquela descrição freudiana), ainda que apresente alguns traços comuns, ou ao menos próximos. Foucault mesmo diz isso na longa entrevista que segue as conferências de As Verdades e as Formas Jurídicas (Foucault, 1994b, p. 625). O Édipo que interessa a Michel Foucault é, na realidade, o texto de Sófocles. Num primeiro instante, portanto, o que lhe interessa é o discurso.

\section{A temática do discurso na genealogia foucaultiana}

Que o discurso de Sófocles em questão, Édipo-Rei, é um discurso
${ }^{1}$ A publicação em questão é o pequeno livro Moi, Pierre Rivière, ayant égorgé ma mère, ma soeur et mon frère. Paris, Gallimard, 1974. Cf. também Defert (1994, p. 44). 
literário, uma autêntica peça de tragédia grega não resta dúvida. Contudo, Foucault não está interessado nas características taxinômicas de um discurso; se é ficção (conto, teatro ou romance), ou poesia, se é um discurso filosófico ou científico, ou ainda se é um discurso mítico, pouco lhe importa. O que lhe interessa é observar o discurso em seu exercício, em sua emergência de acontecimento, isto é, de um ponto de vista pragmático (cf. Foucault, 1994b, p. 631); tendo presente, por um lado, sua relação com práticas sociais e, por outro lado, com outros discursos, identificando aí alguma "espécie de isotopia" (Foucault, 1994b, p. 636).

Nesse sentido, com tais objetivos, Foucault não se considera um estruturalista, principalmente filiado a Lévi-Strauss (cf. Foucault, 1994b, p. 554 e 635 ) pois, segundo ele,

"O estruturalismo consiste em tomar conjuntos de discursos e a tratá-los somente como enunciados, buscando as leis de passagem, de transformação, os isomorfismos entre esses conjuntos de enunciados. Não é isso que me interessa" (Foucault, 1994b, p. 636).

O que significa tal afirmação? No caso de Foucault significa, primeiramente, que a sua negação de que tenha qualquer vínculo com o movimento estruturalista não é, pura e simplesmente, uma negação de vínculo; é mais propriamente uma rejeição de um vínculo, que houve alguns anos antes, entre Foucault e o movimento estruturalista, à época da publicação de Les mots et les choses (precisamente em 1966). É nesse período que Foucault se inebriou com a idéia de uma autonomia absoluta do discurso frente às práticas sociais. Vale observar o conceito de "épistémê", que está no núcleo conceitual de Les mots et les choses, e que é aplicado, precisa e exclusivamente, aos discursos e suas formações discursivas (cf. Foucault, 1994a, p. 158). Tanto é assim que Foucault substitui o caráter documental pelo caráter monumental do discurso, como ele afirma em L'archéologie du savoir (Foucault, 1969, p. 182), ainda que nesse livro de 1969 já admita alguma relação entre os discursos e as práticas extra-discursivas sem, todavia, deixar de atribuir aí uma primazia aos discursos, a partir de suas formações discursivas (cf. Foucault, 1969, p. 44ss, especialmente p. 53).

Assim, o que Foucault considera interessante é efetuar uma análise sobre um dado discurso - no caso Édipo-Rei - mediante a identificação de possíveis relações com outros discursos e com práticas e instituições sociais, principalmente as chamadas práticas jurídicas (dado o objetivo geral das conferências $A$ verdade e as formas jurídicas).

Vale observar ainda que se Foucault pretende aqui se desincompatibilizar com qualquer estruturalismo (com exceção do estruturalismo de Dumézil), isso não equivale a negar o que fizera anteriormente na fase arqueológica (mesmo naqueles seus textos de estilo e propósitos francamente estruturalistas). Quero chamar a atenção para o fato de que Foucault, na sua análise de Édipo-Rei, não negligencia nem a concepção de "formação discursiva" nem de "prática discursiva", conceitos 
utilizados principalmente em 1969, por ocasião da publicação de L'archéologie du savoir.

Esse livro está impregnado de um profundo mal-estar, pois Foucault, envolvido num embate pessoal, se propõe a recapitular suas investigações arqueológicas a partir de uma leitura estruturalista. Esse incipiente estruturalismo, contudo, é defendido ao mesmo tempo em que Foucault já não está mais convicto de seus fundamentos e méritos, de suas causas e conseqüências. Em 1969, ele já não se considera um estruturalista mas se sente obrigado a defender uma concepção estruturalista de arqueologia, provavelmente em função do sucesso editorial que foi Les mots et les choses.

Isso pode ser captado pela própria noção de "discurso". De um ponto de vista estrutural, a concepção foucaultiana de discurso tem que ser pensada por um lado a partir do binômio langue/parole, estabelecido por Saussure em seu Cours de linguistique générale. Isto é, assim como Saussure definiu que o significado de um signo lhe é atribuído arbitrariamente a partir das regras formais estabelecidas pela langue, o discurso é asignificativo se tomado isoladamente, mas não em uma formação discursiva. Essa concepção, sem sombra de dúvida, é bastante problemática em função das estranhas concepções de "regra" e "regularidade" estabelecidas por Foucault, como bem observam Dreyfus e Rabinow (1995, p. 95).

Contudo, ainda que o conceito foucaultiano de "discurso" não seja propriamente um equivalente ao conceito de "parole", empregado por Saussure, existem elementos comuns entre os dois termos: assim como a "parole" é o exercício efetivo e específico da "langue", o "discurso" também tem uma materialidade de exercício; ou seja, o discurso, ainda que respeite regularidades formais inerentes à formação discursiva, tem uma materialidade própria de exercício, pois inerente à concepção estruturalista de "discurso" criada por Foucault há, ambiguamente, traços de uma concepção pragmática, na qual o que importa é seu exercício e emergência, e que condições mínimas devem ser cumpridas para que se dê um determinado exercício de um discurso. É, em linhas gerais, com base nesse dilema que Foucault formulou em L'archéologie du savoir a expressão "prática discursiva".

Note-se, porém, que tal pragmatismo só começa, efetivamente, a aflorar quando Foucault toma o discurso como acontecimento. Isso ocorre em 1968, por ocasião de seu artigo Sur l'archéologie des sciences. Réponse au cercle d'épistémologie (Foucault, 1994d, p. 705). E quando Foucault declara que o que se deve fazer é dar conta de apreender o discurso enquanto acontecimento, o primeiro passo é não considerar sua relação com qualquer estrutura linguística, ou langue, como dizia Saussure (cf. Foucault, 1994d, p. 706).

Essa noção de "acontecimento ", fundamental para a sua concepção pragmática de "discurso", Foucault a toma de, basicamente, duas fontes: primeiramente de Deleuze que, em seu Logique du sens, se põe a discutir sobre o que chamou de "efeitos de superfície"; e em segundo, até em função da leitura daquele texto de Deleuze, de Émile Bréhier, em particular o seu 
pequeno e interessante livro intitulado La théorie des incorporels dans l'ancien stoïcisme. O que Deleuze e Bréhier fazem é apresentar, a partir da concepção lógica dos estóicos, uma outra concepção de linguagem com base em uma teoria proposicional totalmente diferente daquela estruturada por Aristóteles (sujeito-cópula-predicado), descobrindo assim uma nova relação de causalidade entre corpos e linguagem de tal modo que a linguagem é compreendida, enquanto efeito, como um incorpóreo (cf. Deleuze, 1969, p. 12-20; Bréhier, 1989, p. 3-13).

Como se pode facilmente notar, essa concepção pragmática de discurso permanece na fase genealógica de Foucault, passando por sua aula inaugural (cf. Foucault, 1971, p. 53, 55, 59), referindo-se ainda aí à materialidade do discurso como "materialismo do incorporal" (Foucault, 1971, p. 60), expressão de cunho deleuzeano/estóico. No mesmo sentido pode-se notar em $A$ verdade e as formas jurídicas, quando Foucault observa os papéis desempenhados por Sófocles e Platão, em que ao primeiro coube eliminar a íntima relação entre poder e saber, e ao segundo coube transformar essa suposta antinomia ou oposição em mito. Por sua vez, cabe a Foucault e a tantos outros, após Nietzsche, lutar para eliminar o mito e restabelecer, analiticamente, a íntima aliança, que jamais deixou de existir, apesar de camuflada, entre poder e saber. Na averiguação desses papéis de Sófocles e Platão, o que Foucault identifica são os personagens atacados por aqueles pensadores gregos: os sofistas e o tirano (cf. Foucault, 1994b, p. 568).

O que nos interessa, por enquanto, é observar o papel que o sofista ocupa nessa concepção foucaultiana de "discurso": é o sofista bem como os estóicos que possibilitam uma concepção pragmática de linguagem e discurso, contra uma tradição que se firmou, com Platão e Aristóteles, na qual a linguagem é reduzida a sua função declarativa e pela qual a proposição só possui, fundamentalmente, dois elementos: nomes, que se atribuem a objetos (ou se preferir a entes), e o verbo-cópula, que tem por função ligar dois nomes, de tal modo que, basicamente, um é atributo do outro (além disso, vale observar que a cópula - o verbo ser - tem uma ambigüidade tal em função de ser também utilizado como substantivo). Os sofistas, segundo Foucault, compreendem o discurso como efeito e pelos efeitos que pode gerar; pelo seu uso retórico que é, inevitavelmente, um procedimento político, um exercício de poder. É o que ele diz explicitamente:

"se para os sofistas, falar, discutir, é procurar obter a vitória não importa a que preço, e mesmo às custas dos artifícios mais grosseiros, é que para eles a prática do discurso não é dissociável do exercício do poder. Falar é exercer um poder, falar é arriscar-se a ganhar ou perder tudo" (Foucault, 1994b, p. 632).

Desse modo, ainda segundo Foucault, o discurso não tem mera função declarativa e não cabe, portanto, ao genealogista averiguar apenas a verdade ou falsidade de suas proposições. Cabe também averiguar seus usos, suas múltiplas relações com outros discursos e com práticas sociais. 
Em outros termos, compete ao genealogista deslindar a materialidade do discurso enquanto exercício de poder, enquanto estratégia relacionada com outras estratégias sociais (cf. Foucault, 1994b, p. 633 e 636), mesmo no caso de discursos verdadeiros (cf. Foucault, 1994b, p. 634). Mesmo a verdade do discurso deve ser analisada pelo genealogista de um ponto de vista pragmático do discurso (e não há nenhuma outra forma).

É o que Foucault identifica precisamente no Édipo quando este se põe a descobrir as causas da desgraça que se abateu sobre Tebas. Quem é Édipo? Édipo é ao mesmo tempo soberano e juiz; é ele que governa, legisla e julga o povo de Tebas, reunindo assim todas as características básicas do tirano, na Grécia Clássica. "Este - diz Foucault -, nos séculos VII e VI, era o homem do poder e do saber, aquele que dominava tanto pelo poder que exercia quanto pelo saber que possuía" (Foucault, 1994b, p. 568).

Quando a desgraça recai sobre Tebas, cabe a Édipo - que já a tinha libertado das ameaças da Divina Cantora e que por isso tornou-se seu tirano (cf. Foucault, 1994b, p. 565) - novamente restabelecer a ordem.

$\mathrm{O}$ primeiro passo para o restabelecimento da ordem e, por conseguinte, da salvação de Tebas contra a peste, é a consulta ao oráculo de Delfos, que responde em tom profético/divino, que a fonte de todo o mal é o assassinato do rei Laio. É mister, portanto, para a salvação de Tebas, que se descubra o assassino, o autor de ignóbil crime, e que se faça a justiça; e novamente o oráculo responde: Édipo é o assassino. Como Foucault bem observa, toda a verdade já está dita aí no discurso prescritivo e profético do oráculo (cf. Foucault, 1994b, p. 558).

Como tal enunciação profética da verdade não basta, far-se-á necessário que se descubra a verdade por outros meios; por isso, se impõe um mecanismo de obtenção e constituição da verdade que Foucault nomeou de "jogo das metades" (Foucault, 1994b, p. 559). O jogo das metades consiste basicamente na reconstituição da verdade (isto é, da reconstituição discursiva do fato causador dos males de Tebas) a partir da coleta e de um intricado jogo de discursos obtidos ou por profecia, ou por inquérito e testemunho (no caso dos escravos e reis).

O ajustamento de parte dos discursos obtidos (daí a idéia de metades) é feito pelo rei-juiz (Édipo) mediante a consulta ao oráculo e à rainha (Jocasta) - este obtido espontaneamente e de modo casual, isto é, não previsto no jogo de metades - bem como pelo inquérito aos escravos sob ameaça de tortura. Nas falas, isto é, nos discursos dos escravos, um confirma a versão do outro encaixando-se perfeitamente (a confirmação se obtém não pelo julgamento recíproco do discurso de um escravo sobre o do outro, mas porque a versão de um encaixa como a metade perfeita da versão do outro, sem que, necessariamente, um saiba da versão do outro, a não ser o rei-juiz).

Desse modo se obtém completamente a verdade dos discursos dos escravos. Discurso esse não do profeta ou dos deuses, mas da testemunha. Vale, por fim, observar que o que garante a verdade do discurso do escravo, no caso do escravo proveniente de Corinto, é o discurso do 
escravo de Citerão. Não é o recurso aos fatos, à natureza, aos objetos da percepção, ao que for, mas o encaixe não intencional entre dois discursos da mesma ordem, do discurso de testemunho. É essa condição, meio simbiótica, de acoplamento discursivo (isto é, o parâmetro de verdade de um discurso é um outro discurso que o completa) que se dá no jogo das metades.

Qual a diferença entre a verdade profética e a verdade do testemunho? Nenhuma. O que muda é apenas o modo como são obtidas e seus efeitos. A verdade profética é obtida por consulta e a verdade do testemunho é obtida por inquérito mediante o recurso da ameaça de tortura. $\mathrm{O}$ efeito da enunciação profética da verdade é tão somente de expor a fonte de todo o mal que se abateu sobre Tebas (o assassinato de Laio), de apresentar o seu autor/assassino (Édipo), e de exigir que se cumpra a sentença previamente estabelecida pelo rei-juiz (a expulsão do assassino) - nesse último instante, a enunciação da verdade profética se faz prescritiva. Entretanto, o discurso profético da verdade, ainda que exponha todos os fatos importantes sobre a questão, não exerce a função de descrever os fatos tal como aconteceram. Essa descrição é feita pelo discurso-testemunho dos escravos, pois foram eles que tudo viram e ouviram; são os escravos que atestam em seus discursos comprovados como verdadeiros pelo jogo de metades a denúncia do discurso divino (e, portanto, verdadeiro). Ocorre assim um deslocamento, como diz Foucault, mas apenas de enunciação e de olhares; entretanto, a verdade ainda é a mesma. Afirma Foucault mesmo:

"Podemos dizer, portanto, que toda a peça de Édipo é uma maneira de deslocar a enunciação da verdade de um discurso de tipo profético $e$ prescritivo a um outro discurso, de ordem retrospectiva, não mais da ordem da profecia, mas do testemunho. É ainda uma certa maneira de deslocar o brilho ou a luz da verdade do brilho profético e divino para o olhar, de certa forma empírico e quotidiano, dos pastores. Há uma correspondência entre os pastores e os deuses. Eles dizem a mesma coisa, eles vêem a mesma coisa, mas não na mesma linguagem nem com os mesmos olhos. Em toda a tragédia vemos esta mesma verdade que se apresenta e se formula de duas maneiras diferentes, com outras palavras, em outro discurso, com outro olhar. Mas esses olhares se correspondem um ao outro. Os pastores respondem exatamente aos deuses e podemos dizer até que os pastores os simbolizam. O que dizem os pastores é, no fundo, mas de outra forma, o que os deuses já haviam dito" (Foucault, 1994b, p. 561).

A tematização genealógica do poder: a sociedade contra o estado? Um outro aspecto que vale a pena ter presente, e que Sobre o 
Édipo possibilita algumas estimulantes reflexões, diz respeito à temática do poder, temática esta que ocupa um papel nuclear em toda a genealogia.

$\mathrm{O}$ que vem a ser, segundo Foucault, o poder? Sem questionar como o conceito de "poder" foi se constituindo, aqui o que importa observar é como o poder se configura. Gabilondo observa que Foucault, basicamente, estabelece cinco postulados acerca do poder visando criticá-los: a) postulado da propriedade (o poder seria algo conquistado e possuído por alguém ou por uma classe - a dominante); b) postulado de localização (o poder estaria situado no estado ou, conforme Althusser, nos aparelhos ideológicos do estado); c) postulado de subordinação (o poder seria subordinado a um modo de produção, tal como o estado); d) postulado do modo de ação (o poder se exerceria pela repressão e ideologia); e e) postulado de legalidade segundo o qual o poder do estado se expressa na lei (cf. Gabilondo, 1990, p. 160-168).

A crítica de Foucault consiste em mostrar que o poder não deve ser definido em termos de substância, não tem o estatuto ontológico de ente, mas de ação, de exercício (contra o primeiro postulado); e de correlação de forças desiguais e móveis, relações de poder que são imanentes a outras modalidades de relações; relações de poder que não podem ser teoricamente esquadrinhadas por princípios de dominação (como proposto por Marx e Weber, cada um a seu modo) e que, portanto, têm como sua reação imanente qualquer ato de resistência - sendo pois compreendido como contra-poder, mas que só se dá no exercício e relação de poder (cf. Foucault, 1988, p. 8892).

Desse modo Foucault suplanta, um a um, cada postulado daquela representação do poder que ele chamou de "jurídico-discursiva" (Foucault, 1988, p. 80). Como a concepção foucaultiana de "poder" não é explicada pelo princípio de dominação, por conseguinte, o poder não é tomado como um atributo ou coisa que uma classe conquistou, compreendendo-se como dominante. Como Foucault observa, a supremacia política de uma classe é esporádica e eventual de tal modo que uma outra classe (chamada por qualquer teoria da dominação de "classe dominada" ou "classe subordinada") pode tomar o poder, ou melhor, sobrepor-se à força sobre uma outra classe, ou ainda oferecer resistência (por meio de motins ou revoltas), ou mesmo pelo exercício de cidadania cobrando a ação adequada do soberano ou destituindo o soberano de sua soberania. Assim, o que se pode notar é que as relações de poder atravessam todo o tecido social de tal modo que o poder é onipresente nos seguintes termos propostos por Foucault:

"Onipresença do poder: não porque tenha o privilégio de agrupar tudo sob sua invencível unidade, mas porque se produz a cada instante, em todos os pontos, ou melhor, em toda relação entre um ponto e outro. $O$ poder está em toda a parte; não porque englobe tudo e sim porque provém de todos os lugares. (...) o poder não é uma instituição e nem uma estrutura, não é uma certa potên- 
cia de que alguns sejam dotados: é o nome dado a uma situação estratégica complexa numa sociedade dada” (Foucault, 1988, p. 89).

Desse modo, não há porque relacionar poder e estado, uma vez que o estado é apenas uma instituição nas relações sociais que se investe de poder, mas não é a única onde isso ocorre; tampouco é o centro irradiador de poder. Da mesma forma é absurdo para Foucault falar em aparelhos ideológicos de estado como o fez Althusser, pois tal conceito pressupõe que toda e qualquer instituição reflete e repete ideologicamente, tal como uma extensão, o estado enquanto centro irradiador e produtor de poder e dominação.

A análise genealógica de uma instituição tem a sua pertinência na medida em que se identifica aí alguma tecnologia de poder, alguma relação de força específica, ou conjunção de relações de força que permeia aquela instituição específica ou a sociedade como um todo. Mesmo quando certas relações de poder, como o poder disciplinar, estão presentes na sociedade como um todo, Foucault analisa tais relações aí - na sociedade e em suas instituições sociais - sem, contudo, reportar-se obrigatoriamente ao estado. Antes, qualquer análise acerca das relações de poder alocadas no estado toma como referência as relações de poder na sociedade.

Assim, o que Foucault faz é uma inversão: em vez de estudar as relações de poder a partir do estado, compreende o estado como uma dentre outras instituições sociais e estuda, pois, as relações de poder na tessitura social. O que importa a Foucault, em Vigiar e Punir, não é tanto estudar o surgimento das prisões mas a constituição de um determinado tipo de poder - o poder disciplinar - configurando uma determinada sociedade - a nossa, isto é, a moderna - como disciplinar, que tem no panoptismo (idealizado por Bentham e interpretado por Foucault) a suprema idealização dos poderes de disciplinar e de vigiar.

"O arranjo Panóptico - afirma Foucault - dá a fórmula dessa generalização. Ele programa, ao nível de (sic!) um mecanismo elementar e facilmente transferível, o funcionamento de base de uma sociedade toda atravessada e penetrada por mecanismos disciplinares" (Foucault, 1987, p. 184).

E, posteriormente, Foucault caracteriza em termos precisos a nossa sociedade como disciplinar:

"Nossa sociedade não é de espetáculos, mas de vigilância; sob a superfície das imagens, investem-se os corpos em profundidade; atrás da grande abstração da troca, se processa o treinamento minucioso e concreto das forças úteis; os circuitos da comunicação são os suportes de uma acumulação e centralização do saber; o jogo dos sinais define os pontos de apoio do poder; a totalidade do indivíduo não é amputada, reprimida, 
alterada por nossa ordem social, mas o indivíduo é cuidadosamente fabricado, segundo uma tática das forças e dos corpos" (Foucault, 1987, p. 190).

\section{A tematização genealógica do indivíduo: poder, discurso e sujeição}

$\mathrm{Na}$ citação acima fica evidenciada a relação que se estabelece entre poder, saber e constituição do indivíduo. A vigilância disseminada em todos os níveis da tessitura social, imbuída de uma consciência da vigilância hierárquica (por parte de quem é vigiado), ao mesmo tempo que é anônima (a consciência da vigilância hierárquica independe do conhecimento de quem vigia, do sujeito da vigilância), impõe uma docilidade e um adestramento físico gerando eficiência comportamental. É desse modo que se estabelece uma relação entre poder e indivíduo, na medida em que o indivíduo não é tomado nem como átomo nem como base das relações sociais, isto é, como premissa lógica das relações sociais e políticas, como apregoa, em suas linhas gerais, o liberalismo (cf. Pizzorno, 1989, p. 236); antes o indivíduo é compreendido como o efeito de uma conjugação estratégica de forças, pelas mais diversas tecnologias de constituição dos indivíduos, gerando delinqüentes, desviantes sexuais... que propiciam o surgimento de novos saberes, reclamando o estatuto de cientificidade e de tal forma que se configurem como verdadeiros (eis aí a vontade de verdade à qual Foucault já fazia menção desde 1971 em seu primeiro curso no Collège de France). Assim foi com a medida na Grécia Antiga, com o inquérito na Idade Média e o exame na sociedade moderna, que foi "matriz de todas as psicologias, sociologias, psiquiatrias, psicanálises, em suma, de tudo que se chama de as ciências do homem" (Foucault, 1979b, p. 171).

Um outro bom exemplo de tecnologia de poder que constitui os indivíduos e que possibilita a constituição de um saber é a confissão, na qual o indivíduo instigado a confessar torna-se sujeito do enunciado e da enunciação discursiva (é ele que fala e não aquele que o instiga a falar) e da verdade de seu discurso-confissão (cf. Foucault, 1988, p. 61) que deve, portanto, ser registrado e arquivado, e que as técnicas de sua produção devem ser disseminadas (cf. Foucault, 1988, p. 63), possibilitando assim a constituição de uma ciência que tem no sujeito da confissão, e na própria confissão, o núcleo temático de seu discurso. Desse modo, portanto, uma ciência, ou um saber com pretensões científicas, embasada na prática da confissão é, em larga medida, um discurso sobre outros discursos que, por sua vez, relatam a individualidade do seu sujeito, desnudando-a completamente, tanto para o sujeito da confissão quanto para o "cientista" que exige e colhe a confissão (cf. Foucault, 1988, p. 64-69).

Contudo, Édipo-Rei não é uma tragédia dos nossos tempos. Nela não temos a totalidade dos elementos aqui mencionados, embora diga muito a nosso respeito, na medida em que se vincula com nossa modernidade na condição de passado (embora não no sentido de uma continuidade teleológica ou histórica, mas sim numa relação de descontinuidade relativa). Como é,
${ }^{2}$ Foucault utiliza-se dos dois termos, não como sinônimos, mas como expressões, parciais e complementares, de sua concepção de poder. Para tanto, cf. Foucault (1988, p. 15, 26, 55, 89 e 98 ). 
Contudo, vale observar que somente a verdade do discurso profético de Apolo não é questionada; a profecia de Tirésias - ainda que seja a profecia de um oráculo - é questionada por Édipo na medida em que este o acusa de complô à sua soberania. Assim, pois, não só a verdade da profecia do oráculo é insuficiente por estar impossibilitada de submeterse à comprovação bem como é questionada, ainda que de um ponto de vista político (cf. Foucault, 1994b, p. $563)$. então, o exercício de poder apresentado em Édipo-Rei?

Basicamente, a tecnologia de poder que Foucault identifica nessa tragédia é uma modalidade peculiar de inquérito, que tem como estratégia ou mecanismo ${ }^{2}$ de poder o que ele chamou de "jogo das metades": primeiramente o inquérito dos escravos é apreendido por meio de ameaças de tortura; em segundo lugar, os testemunhos são obtidos separadamente sem que nenhum dos escravos saiba dos demais discursos obtidos; e em terceiro lugar, os testemunhos (e não os escravos) são contrapostos frente a frente de tal modo que os relatos se complementam parcialmente constituindo assim a verdade buscada. Édipo, como soberano e juiz, está plenamente imbuído do direito de torturar e punir, tem direito de vida e morte sobre os cidadãos de Tebas e faz uso de seu direito contra dois escravos (que não são cidadãos e que são estrangeiros), e é na condição de possuidor de tais direitos que promete expulsar o autor do assassinato de Laio.

Deve-se observar, entretanto, que Foucault entende o "jogo das metades" não como um simples jogo de confissão e inquérito. Tanto é que Édipo recolhe, tal como peças de um quebra-cabeças, as predições oraculares e algumas afirmações da rainha Jocasta. Esses discursos são recolhidos por consulta. Entretanto, Foucault mesmo o diz, toda a verdade sobre o assassinato já é dada pelos discursos do deus e de seu oráculo. Por que a verdade de tal discurso não basta? Porque não cumpre as exigências mínimas da vontade de verdade da sociedade grega. Os testemunhos dos escravos são fundamentais para o cumprimento de tal exigência. Não basta mais nem o juramento perante os deuses para atestar a verdade, como aparece na Ilíada de Homero, nem o discurso profético do oráculo de Delfos - essas duas formas que estão presentes no início da peça Édipo-Rei. Todavia, enquanto o juramento é totalmente desconsiderado, o discurso profético ocupa o ponto inicial na estratégia/mecanismo de obtenção da verdade; a profecia é simultaneamente a primeira informação que Édipo recolhe na sua empreitada de descobrir a verdade sobre o assassinato de Laio bem como a verdade toda sintetizada numa resposta.

O que desqualifica a suficiência da profecia é sua enunciação, ela é feita no tempo futuro, como se ainda fosse acontecer (cf. Foucault, 1994b, p. 558). O que se exige, porém, é a comprovação da verdade, coisa que não se pode obter das profecias divina e oracular, ainda que a sua verdade não possa ser questionada ${ }^{3}$. A comprovação da verdade só pode se realizar sobre um discurso que declare coisas sobre o presente e o passado, sobre coisas que ocorreram. Esse discurso que agora é reclamado a fazer parte da plêiade dos discursos verdadeiros, e que atende à exigência da comprovação da verdade, é o testemunho. Diz explicitamente Foucault:

"Temos toda a verdade, mas na forma prescritiva e profética que é característica ao mesmo tempo do oráculo e do adivinho. A esta verdade que, de certa forma, é completa e total, em que tudo foi dito, falta entretanto alguma coisa que é a dimensão do presente, da atualidade, da designação 


\section{de alguém. Falta o testemunho do que realmente se passou. Curiosamente, toda esta velha histó- ria é formulada pelo adivinho e pelo deus na for- ma de futuro. Precisamos agora do presente e do testemunho do passado: o testemunho presente do que realmente aconteceu" (Foucault, 1994b, p. 558; grifo nosso).}

Desse modo, parece-me plausível afirmar que o núcleo dessa estratégia/mecanismo de obtenção de verdade está no processo de confissão e inquérito submetido aos escravos. Esse inquérito, como já mencionei anteriormente, Édipo o obtém, provoca-o pela ameaça de tortura; o discursotestemunho é obtido no inquérito graças a um recurso de poder: a ameaça de tortura. Tem-se aí duas ações, por assim dizer: a ação do inquérito, do discurso-testemunho, e a ação da ameaça de tortura. A ação da ameaça de tortura se impõe sobre o indivíduo, sobre o escravo, sobre seu corpo e mesmo sua vida; é essa ação impositiva da ameaça que garante e possibilita o testemunho, e desse modo é uma ação que instiga, que provoca outra ação como seu efeito e que também condiciona essa ação-efeito que é o discurso na forma de testemunho (e não como profecia).

Ora, a ação de ameaça nada mais é que o exercício de poder, e todo o processo de obtenção desse testemunho é o que Foucault chamou de "relações de poder". O exercício de poder, afirma Foucault,

"é um conjunto de ações sobre ações possíveis; ele opera sobre o campo de possibilidade onde se inscreve o comportamento dos sujeitos ativos; ele incita, induz, desvia, facilita ou torna mais difícil, amplia ou limita, torna mais ou menos provável; no limite, ele coage ou impede absolutamente, mas é sempre uma maneira de agir sobre um ou vários sujeitos ativos, e o quanto eles agem ou são suscetíveis de agir. (...) O exercício do poder consiste em "conduzir condutas" e em ordenar probabilidades. O poder, no fundo, é menos da ordem do afrontamento entre dois adversários, ou do vínculo de um com relação ao outro, do que da ordem do 'governo'." (Foucault, 1994c, p. 237).

Assim, pode-se também observar que o poder incita o surgimento e a proliferação de discursos, bem como provoca nos indivíduos, ou melhor, condiciona fisicamente os indivíduos de tal modo que se tornam sujeitos dos discursos. Foi o que Édipo fez com os escravos. O poder faz mais: possibilita o acoplamento parcial dos discursos constituindo, então, a verdade desses discursos pela comprovação dessas verdades (que coincide com esse acoplamento). Conseqüentemente, não há como negligenciar a relação entre verdade e poder. Segundo Foucault, a verdade é da ordem do poder; é graças ao exercício e às relações de poder que a verdade se constitui, ou melhor, que um discurso se qualifica como verdadeiro. 
Como expus anteriormente, em A verdade e as formas jurídicas, assim como na genealogia desde seu início, Foucault defende uma concepção pragmática de discurso e de verdade; não lhe importando tanto as suas características epistemológicas (é provável que tampouco as suas características ontológicas). Pode-se, agora, concluir que há uma certa coincidência entre sua concepção pragmática de discurso e sua concepção de poder na medida em que o poder tem capacidade produtiva, pois gera, prolifera e condiciona os discursos de tal modo que os torna verdadeiros ou não.

\section{A tematização genealógica do indivíduo: sujeição e governo}

No caso de Sobre o Édipo, é apenas o chefe do governo e/ou o senhor da justiça, Édipo, que gera, prolifera e condiciona os discursos. É ele que consulta Apolo e seu oráculo, é também ele que recolhe (ainda que não o tenha provocado) o testemunho de Jocasta e, em função disso, suas próprias lembranças. Por fim, e creio que mais importante, é Édipo que obriga os escravos a testemunharem e, só após os dois relatos, pela sua conjunção, que tais discursos ganham contornos (pragmáticos) verdadeiros. Se os escravos são sujeitos desses discursos verdadeiros, discursos-testemunhos, não o são como premissas, não são dados previamente ao acontecimento discursivo; são na realidade constituídos pelo exercício de poder de Édipo no exato instante em que são obrigados a falar.

Mas e Édipo? Como ele se enquadra nesse complexo jogo de poder e de saber no qual se produz discursos, verdades e individualidades (sujeitos)? Seria ele a fonte geradora do jogo e, por conseguinte, a premissa do mesmo? Assim como os escravos, Édipo, ou melhor, o governante, enquanto indivíduo e sujeito, não ocupa um papel "apriorístico", tal como premissa lógica, às relações de poder. Não é Édipo que importa, nem propriamente o governante (tirano). O que importa são as relações de poder que se estabelecem no corpo da sociedade de tal modo que condicionam os papéis e as funções dos agentes sociais; a própria condição de agente social varia em conformidade com sua constituição topológica nas relações de poder (que, ambiguamente, em Foucault, tanto coincide com as relações sociais quanto lhes serve de princípio interpretativo).

O que importa, então, é o papel que Édipo ocupa naquelas relações de poder identificadas por Foucault na tragédia de Sófocles, que determinam tanto sua condição de governante quanto seu exercício de poder (só Édipo enquanto tirano pode instituir o inquérito e o jogo das metades). A sua condição de governante, bem como todo poder político, é interpretada pelo genealogista a partir das relações de poder e, portanto, de sua individualidade de sujeito. Desse modo, pode-se dizer, a partir de Sobre o Édipo, que as relações de poder efetuam diferenciações nas individualidades, sujeitandoas sempre. Como observa Foucault,

"Esta forma de poder aplica-se à vida quotidiana imediata que categoriza o indivíduo, marca-o com sua própria individualidade, liga-o à sua 
própria identidade, impõe-lhe uma lei de verdade, que devemos reconhecer e que os outros têm que reconhecer nele. É uma forma de poder que faz dos indivíduos sujeitos" (Foucault, 1994c, p. 227).

É isto que se pode notar em Édipo. Não importa muito a Foucault o fato de Édipo ter matado o próprio pai e de ter estabelecido relações incestuosas com sua mãe, Jocasta. O que lhe interessa (e segundo ele também a Sófocles), é a sua realeza, é o seu poder político, de soberano (cf. Foucault, 1994b, p. 562). Esse seu poder político e sua individualidade, seu assujeitamento enquanto governante, são estudados por Foucault no âmbito das relações de poder. E a genealogia das relações de poder implica, dentre outras coisas, averiguar o regime de saber. Em Sobre o Édipo, esse regime de saber é apresentado de várias formas: pelo jogo das metades enquanto símbolo grego, na medida em que reagrupa discursos os mais variados e constitui uma verdade, a verdade do fato testemunhado; pelo saber de Édipo que é da ordem da experiência e que se auto-constitui, em suma, "saber autocrático do tirano que, por si só, pode e é capaz de governar a cidade" (Foucault, 1994b, p. 567).

Eis o que Foucault evidencia: Édipo, ou melhor, poder político e saber não são incompatíveis nem excludentes, como pretenderam afirmar, cada um a seu modo, Platão e Sófocles, e que ainda assim constituíram uma tradição política e epistemológica, que formou o mito da incompatibilidade entre poder e saber (cf. Foucault, 1994b, p. 570). Por outro lado, e de modo mais "positivo", o que ele, Foucault, tentou mostrar é que saber e poder são indissociáveis e que se auto-condicionam, formando uma totalidade única e coesa, embora complexa, e que, apesar do mito da incompatibilidade entre poder e saber, tal unidade jamais foi abalada, quanto mais dissolvida (cf. Foucault, 1994b, p. 569).

É com base nesse contexto que Foucault busca explicar a obsolescência de Édipo: ele podia e sabia demais; Édipo ultrapassou os limites do bom governo, que estrategicamente não lhe ameaçariam politicamente. O exercício de sua força, de seu poder infringia os limites das relações de poder nas quais estava inserido, não pesando as consequiências de seu exercício; ele levou até as últimas conseqüências o seu poder, exerceu de modo demasiado suas forças no jogo das metades. O resultado primeiro foi a reconstituição do fato do assassinato pelo testemunho e sua consequiência mais extrema, mas inevitável, foi a perda de sua sujeição de governante, foi sua transformação de tirano em personagem inútil a todas as relações de poder que se dão em Tebas; ou seja, quando toda a verdade é desnudada, Édipo, o assassino do rei Laio, é deposto de sua condição de tirano e deportado de Tebas.

As relações de poder e as suas relações com o saber se deram plenamente, tal como um complexo mecanismo, seu exercício foi completo e seu resultado último foi a inutilidade constituída de Édipo (cf. Foucault, 1994b, p. 567). Vê-se aí, pois, como a instituição do estado não pode servir 
como referencial teórico para a análise das relações sociais e da sociedade. O que Foucault fez, portanto, foi deslocar o centro interpretativo do estado para as relações de força, para as relações de poder. É com base nessas relações de poder que Foucault explica as relações e as instituições sociais, a constituição de saberes e de indivíduos.

E como já mencionei anteriormente, não há propriedade do poder, uma vez que ele não é substância mas uma modalidade de relação (ao mesmo tempo que matriz de relações sociais diferenciadas). É com base nessa idéia de poder enquanto relação que Foucault interpreta o papel da população de Tebas na tragédia de Sófocles: ela exerce seu papel nas relações de poder com Édipo destituindo-o do governo (cf. Foucault, 1994b, p. 564). As relações de poder, tais como Foucault as compreende, subvertem a primazia do estado frenteà sociedade, bem como às relações sociais, como em geral muitos teóricos e cientistas políticos concebem. Mas as relações sociais enquanto relações de força não destroem necessariamente nem o estado, nem o governo, nem mesmo o regime político; pois, na realidade, as relações de poder lhes são antecedentes; daí que, para Foucault, é perfeitamente plausível a identificação de uma similaridade entre regimes políticos democráticos e regimes autoritários, como o fascismo e o stalinismo. O povo de Tebas não destrói as relações de governo e tirania, apenas destitui Édipo da soberania. Foucault não propõe uma nova utopia social, apenas (e paradoxalmente bem mais) propõe uma nova compreensão das relações sócio-políticas.

\section{Para concluir}

Assim, com base no texto da Segunda Conferência de A verdade $e$ as formas jurídicas - que denominamos Sobre o Édipo - pode-se observar alguns temas constantes na reflexão genealógica de Foucault, tais como:

1. O conceito de "discurso" concebido por Foucault nessa conferência trouxe uma série de elementos da fase arqueológica, mas já se apresenta como uma concepção pragmática de discurso;

2. essa concepção pragmática de "discurso" coincide com sua concepção de poder, enquanto relações de força;

3. essa concepção de "poder" é fundamental para explicar a constituição e proliferação de discursos e, por conseguinte, de saber;

4. o poder é elemento importante na constituição de discursos verdadeiros;

5. o poder produz e diferencia individualidades e sujeitos (sejam eles escravos ou senhor, ou governante);

6. o poder político do governo e do estado podem e devem ser compreendidos a partir das relações de poder que lhes antecedem estruturalmente, e não que se irradiam a partir deles.

Ora, esses temas genealógicos estavam todos presentes, quer 
suficientemente desenvolvidos ou expostos de maneira embrionária, na leitura foucaultiana do Édipo-Rei de Sófocles. Desse modo, Sobre o Édipo ocupa tanto o papel de síntese do que fora desenvolvido por Foucault até aquele momento bem como de discurso-programa na medida em que já anunciava algumas das incursões teóricas e analíticas que Foucault desenvolveria nos anos seguintes.

Daí o mérito e a grandeza de Sobre o Édipo na genealogia foucaultiana.

Recebido para publicação em junho/2000

NALLI, Marcos Alexandre Gomes. Foucault's Oedipus. Tempo Social; Rev. Sociol. USP, S. Paulo, 12(2): 109-128, novembro de 2000

ABSTRACT: In this text the author tries to recover the theoretical-conceptual elements fundamental to the genealogical analysis, based on Foucault's Second Conference of "The Truth and the Juridical Forms", especially identifying a pragmatic concept of discourse, linked in a fundamental way to the genealogical concept of power, with its unfoldings regarding the issue of state and government, as well as that of the individual.

KEY WORDS: genealogy, discourse, power, government, individual.

\section{REFERÊNCIASBIBUOGRÁFICAS}

BRÉHIER, Émile. (1989) La théorie des incorporels dans l'ancien stoïcisme, Paris, Vrin.

DEFERT, Daniel. (1994) Chronologie. In: FOUCAULT, Michel (org.). Dits et écrits. vol. I. Paris, Gallimard, p. 13-64.

DELEUZE, Gilles. (1969) Logique du sens. Paris, Les Éditions de Minuit.

DREYFUS, Daniel \& RABINOW, Paul. (1995) Michel Foucault: uma trajetória filosófica. Rio de Janeiro, Forense Universitária.

ÉRIBON, Didier. (1990) Michel Foucault. São Paulo, Companhia das Letras.

FOUCAULT, Michel. (1969) L'archéologie du savoir. Paris, Gallimard. . (1971) L'ordre du discours. Paris, Gallimard. 
. (1979a) A sociedade punitiva. In: KREMER-MARIETTI, Angèle (org.). Introdução ao pensamento de Michel Foucault. Rio de Janeiro, Zahar, p. 174-187.

(1979b) Teoria e instituições penais. In: KREMER-MARIETTI, Angèle. (org.). Introdução ao Pensamento de Michel Foucault. Rio de Janeiro, Zahar, p. 170-173.

. (1987) Vigiar e punir. Petrópolis, Vozes.

. (1988) A vontade de saber. Rio de Janeiro, Graal.

. (1994a) Entretien avec Michel Foucault. In: Dits et écrits, Tome II. Paris, Gallimard, p. 157-174.

. (1994b) La vérité et les formes juridiques. In: Dits et écrits, Tome II. Paris, Gallimard, p. 538-646.

. (1994c) Le sujet et le pouvoir. In: Dits et écrits. Tome IV. Paris, Gallimard, p. 222-243.

- (1994d) Sur l'archéologie des sciences. Réponse au cercle d'épistémologie. In:

Gallimard, p. 696-731. . Dits et écrits. Tome I. Paris,

GABILONDO, Angel. (1990) El discurso en acción: Foucault y una ontologia del presente. Barcelona, Editorial Anthropos.

MARTON, Scarlett. (1985) Foucault leitor de Nietzsche. In: RIBEIRO, Renato Janine. Recordar Foucault. São Paulo, Brasiliense, p. 36-46.

PIZZORNO, Alessandro. (1989) Foucault et la conception libérale de l'individu. In: CANGUILHEM, Georges (org.). Michel Foucault philosophe. Paris, Seuil, p. 236-245. 